\title{
Galileo's Revenge: Ways of Construing Knowledge and Translation Strategies in the Era of Globalisation ${ }^{1}$
}

\author{
Karen Bennett \\ Centre for Comparative Studies, University of Lisbon.
}

Every schoolchild in England knows the story of Galileo - his confrontation with the Catholic Church in 1616 over Copernicanism, the injunction issued against him, and his eventual trial and disgrace in 1633. In our culture, the event is usually portrayed as the first major conflict in a long war between religion and science, in which the latter was to emerge as inevitably victorious. Moreover, the battle is rarely presented objectively: instead, it is recounted in terms of the gradual removal of a veil of misrepresentation about the natural world that had for centuries been held in place by the interests of the Church. It is the story of Truth triumphing over Faith, Fact over Dogma, complete with 'happy-ever-after' ending in which all the modern marvels of progress and technology are brought to bear.

Today, however, with the erosion of the credibility of positivism and the undermining of the authority of science from a variety of different sources, it is less easy to sustain this somewhat simplistic account of the story. Instead, we would do better perhaps to view it in culturalist terms, as the conflict between two paradigms of

\footnotetext{
${ }^{1}$ This is an electronic version of an article published in the journal Social Semiotics 17.2 @ 2007, copyright Taylor \& Francis. Social Semiotics is available online at: http://www.tandfonline.com/doi/abs/10.1080/10350330701311470
} 
knowledge. These might briefly be summed up as an anthropocentric world view, on the conservative side, a language-oriented attitude to knowledge, which had been inherited from medieval scholasticism and drew not only upon the scriptures but also upon a long tradition of Classical rhetoric; and an upstart new attitude (which we could label as the scientific position), according to which knowledge was to be found not by interpreting words or symbols, but through systematic observation and study of the natural world. ${ }^{i}$

In most of the English-speaking world, the victory of the latter has been total. Religion receded into the private sphere, where its domain was restricted to issues of morality and little more; and science became enshrined as the ultimate authority of truth about the world. Indeed, this shift is reflected in the English language itself for the word 'science', which originally meant 'knowledge', now refers only to the kind of learning supplied by subjects like physics and chemistry. The prestige that is attached to its procedures and results is evident from the efforts made by borderline disciplines like psychology, sociology and linguistics to be accepted as scientific; while even subjects like literary criticism, which can trace their genealogy back to the humanistic approach of the medieval grammar schools, are under pressure to be as empirical as possible.

In the domain of discourse, the consequences of this change have been no less profound. With the shift of attention away from man and his sign systems to the outside world, there was a need for a new kind of discourse, one better suited to the new paradigm. Consequently, the seventeenth century saw a move away from the elaborate rhetoric that had been fashionable in the Renaissance towards a much terser style that was felt to reflect reality in a more direct way. The result is that, today, academic writing in English across disciplines, and indeed factual writing of any type, employs what Venuti 
(1995: 5) calls the 'authoritative plain style' - a style that is so prevalent that most people who have been brought up in the English-speaking world do not even notice it is there.

Indeed, the scientific paradigm has so completely taken over our world that we also have difficulty in conceiving that other approaches to knowledge might still exist. And yet they do. The shift in attitude that came to be known as the Scientific Revolution did not occur uniformly all over the globe, and we do not have to go as far afield as the Middle East to find societies where religion, rather than science, continues to be an important authority. Even in Europe, countries like Spain and Portugal, where the Catholic Church, reinforced by highly conservative political regimes, exerted a powerful influence over many aspects of public policy for centuries, the anthropocentric paradigm has retained a much more central position. This has had an effect upon all areas of life, ranging from the organization of the education system and economy to the role of the media. Not least, we can see its influence in the kind of discourse favoured in academic milieus, a discourse that is often elaborate and literary, in short very different from the direct plain style cultivated in English academic institutions.

This naturally raises serious questions for the practice of translation. Given the hegemony of English in the world, academics who wish to gain recognition on the international scene must inevitably publish in English-language journals, and this means being subject to rigorous selection procedures that may be based upon very different criteria to those at work in their home cultures. In a situation where few people are aware of the underlying power issues, the result may be a kind of discursive schizophrenia, not only for the authors of the texts, but also for the translators that are frequently enlisted as mediators. Required to recast the work in a form that is entirely incompatible with the 
underlying value system of the original, these are often faced with a thankless task that obliges them to choose between the frying pan and the fire - either chastisement by frustrated authors who feel that their precious words have been perverted, or a roasting on the academic community's bonfires for failure to comply with basic research norms.

In short, the clash of paradigms that occurred in Galileo's trial before the Holy Office in 1633 is still being played out on a daily basis at the interface of cultures. However, now the roles are reversed. The ideology that was once at the centre of the polysystem has been relegated to the periphery, considered by many to be an epigone, ${ }^{\text {ii }}$ while the scientific worldview is firmly enthroned at the centre, decreeing what may legitimately be considered as knowledge and what should be excluded as heresy.

Galileo, it seems, has had his revenge.

\section{Discourses and Ideologies}

The notion that discourses might encode ideology in their very structure lies behind the approach to texts known as Critical Discourse Analysis (CDA), which I will be using here. According to this, discourse is perceived as a form of social practice, necessarily embedded in the value system of the culture that gave rise to it. Consequently, language is never innocent. The syntax and lexis of the simplest sentence will reveal value choices that relate it synchronically and diachronically to other texts, thus constructing a complex web of interconnections, which, when institutionalized, may form a coherent discourse with its own ideology, history and agenda. The shifting relations between paradigms that we have discussed in the introduction to this essay are thus manifested textually as 
clashes of discourses, not only between but also within individual works (cf. for example, Kress, 1988; Fairclough, 1992).

It is no accident that this conception of discourse originated in France with the work of the Post-Structuralists. For in the English tradition, a quite different attitude to language has prevailed for much of the modern period. According to this, it is possible (and desirable in many contexts) for language to be purely instrumental, a neutral transparent vehicle of information. As such, the content of a text is perceived as being separable from its form (the cognitive linguists Lakoff and Johnson, [1980:89-96], speak of the prevalence of the 'container metaphor' in our implicit assumptions about language) and thus can be extracted, reformulated, summarized and translated into other languages without any loss or alteration of meaning.

This view of language is predicated upon the belief that there exists an external reality that is independent of human perception and sign systems, which can be observed, analysed and discussed in an entirely objective fashion. But as we have seen, this notion has not always been with us. Until around the time of Galileo's fateful confrontation with the Holy Office, an entirely different theory of knowledge was dominant in England, as in the rest of Europe, and it took several hundred years and a series of profound social, political and economic upheavals for the new paradigm to achieve the hegemonic status that it has today.

In the medieval period, the focus of all learning was not the physical world as separate from man, but rather man's symbolic systems, the work of his spirit. Knowledge, understood as philosophy, resided above all in words, and was acquired by the exegesis of authoritative texts (not only the scriptures, but also those classical texts 
which had been assimilated into the system) and by training in the use of language. Even the 'Book of Nature' was conceived as a symbolic code of non-verbal signifiers, to be interpreted by readers skilled in perceiving similitudes. The educational curriculum naturally reflected this focus, and in schools, the tripartite study of language occupied a central role (the so-called Trivium of Grammar, Rhetoric and Dialectic, of which Dialectic, or the art of argumentation, held pride of place); while in the Universities, Logic, alongside Theology, was the leading discipline. Indeed, words were considered to be manifestations of divine power, and as such, had immense metaphysical and religious importance (cf. Timmermans, 1999: 83-90; Vickers, 1993: 25-28).

In the Renaissance period, with the arrival of Humanism, the arts of verbal expression were given an even bigger role to play, but with a slightly different emphasis. Now rhetoric, or the manipulation of words in order to persuade, took centre stage, regaining much of the importance that it had once had in classical times. According to Christian humanists like Erasmus, language was a civilizing force, a God-given faculty, which could move men to virtue and bring about peace, justice and liberty. Hence, eloquence was cultivated as an educational discipline and literary ideal and abundant speech was valued as an indication of inner worth.

Indeed, 'copiousness' was one of the main aims of the humanist rhetoricians. There was a delight in multiplicity and diversity, and meaning was not perceived as something fixed and immutable, but rather as a variable that would change according to collocation and circumstance. As the objective was not to achieve certainty beyond rational doubt (that was the domain of logic and mathematics) but rather to win the agreement of the particular reader or listener, the interpersonal dimension of language 
was highly valued and students were trained to adapt arguments and style to their audiences. To achieve this goal, they would naturally be expected to make use of the full gamut of figures and tropes at their disposal. In a society in which the divorce between matter and spirit had not yet taken place, these were not perceived as mere ornament, but rather as an intrinsic and essential part of the discourse; like the columns and peristyles on Elizabethan houses, they contributed to the perfection of the whole.

It was, however, during the seventeenth century, that we started to see the first manifestations in England of a change of attitude towards knowledge and language. The reasons for this are complex and various, but an important engine was surely the Reformation, which, in promoting the doctrine of the 'priesthood of all believers' paved the way not only for democracy but also for science and capitalism. iii Excessive ornamentation in all aspects of life, prose style included, began to be distrusted as smacking of superficiality and sophistry; the traditional methodology of the Scholastics came under fire, as did the copious rhetoric of the humanists, and there were calls for a new kind of knowledge based upon direct observation of nature rather than upon the study of texts. An important herald of this shift in attitude was Francis Bacon, whose Novum Organum (1620) urged induction (combining the rational and empirical) as the correct way of investigating nature, as opposed to the Aristotelian system of deduction, which was still the basis of university education at that time.

In his Advancement of Learning (1605), Bacon turned his attention to language, criticizing as 'the first distemper of learning' the tendency to 'study words, and not matter'. 
It seems to me that Pygmalion's frenzy is a good emblem or portraiture of this vanity, for words are but the images of matter, and except they have life of reason and invention, to fall in love with them is all one as to fall in love with a picture.

Terms like 'vanity' and 'images' in this passage, like of course his famous 'idols' in Novum Organum (1620), clearly echo Protestant objections to semiotic phenomena in general and establish a conceptual framework for a discourse about the relationship between language and reality that has persisted into our own days. Man-made signs and symbols are clearly perceived as barriers to a truth that can and should be experienced directly.

Hence, in English, there started to be a move away from the elaborate Ciceronian rhetoric that had been fashionable in the Elizabethan age towards a much terser plain use of language, the so-called Attic style (cf. Croll, 1966:167-202; Partridge, 1969:70). While in the Renaissance, this had been just one of three rhetorical styles taught in schools and universities, and from which an orator could choose according to his theme, line of thought and audience, from the seventeenth century onwards, it started to be perceived as the only valid one for science. This was partly owing to the democratizing agenda of the Protestant scientists, for the new knowledge was widely disseminated to anyone who could read by means of popularizing texts and translations (Hill, 1997:21-31); but, more than this, it was also part of a broader quest to discover and disseminate Truth. As Sacvan Bercovitch (1975:29) points out: 
To speak plainly was not primarily to speak simply, not at all to speak artlessly. It meant speaking the Word; language itself became an Imitatio Christi.

The process begun by Bacon was continued in England by other important figures of the period, notably Hobbes, Locke, and Newton (see Halliday, 1993). Meanwhile, Cartesianism was creating a rift in the formerly holistic approach to learning by its emphasis on reason at the expense of emotion. Over the next two centuries, this was manifested in a wholesale redefinition of what constituted knowledge. The growing status of the natural sciences (as a consequence of their utilitarian associations with technology and business) gradually led to a rupture between Fact and Fiction, according to which the term 'science' became restricted to a very narrow field of study, namely the rationalempirical exploration of the external world. Art and literature, at the other extreme, as non-utilitarian and therefore luxury pursuits, gained a kind of pseudo-spiritual aura, leading to their simultaneous idealization and marginalization (see Hayden White, 1997:24).

The language-based disciplines of the humanities, in the meantime, hovered on the border between the two. Having for centuries been associated with the liberal education provided for young noblemen at the prestigious public schools and traditional universities, and defended by figures such as Newman and Arnold, they were able for some time to retain their more holistic approach to knowledge, leading to the kind of "two cultures' situation famously described by C.P.Snow in 1959. However, as Stefan Collini points out in the introduction to the 1998 edition of Snow's essay, the situation is not 
quite the same today. Pressured by the need for funding and status (and indeed to justify their existence in the face of increased utilitarianism of society), the humanities have been forced to become more 'scientific'; one of the ways in which this is manifested is in the adoption of the discourse of factuality.

Today, the 'authoritative plain style' is so prevalent that most people who have been brought up in the English-speaking world do not even consider it to be a style at all. Convinced as we are that meaning is a timeless and universal essence, easily transmittable between languages and cultures regardless of the change of signifiers' (Venuti, 1995:61), we expect prose to be as clear and transparent as a window, and not to draw attention to itself unnecessarily. When it does so, in the non-literary context, we assume right away that it is deficient, that the author is lacking in skill. Rarely do we consider the possibility that the text might be predicated on an entirely different philosophy of language.

Yet, in some parts of Europe, for cultural and historical reasons, a whole different attitude to knowledge and discourse has indeed prevailed. The countries concerned are inevitably strongly Catholic, and thus bypassed the Protestant-led scientific revolution that propelled northern Europe into the new paradigm. Education systems controlled by Jesuits and feudal pre-industrial economies maintained by conservative political regimes ensured that Enlightenment values never really took hold; this meant that the anthropocentric paradigm was able to persist for much longer, with consequences on all levels. 


\section{Academic Discourse in Portugal}

If we are to identify any one characteristic of Spanish and Portuguese culture that might account for these countries' reluctance to assimilate the scientific paradigm, it might be the profound religiosity at their heart. This goes far beyond mere formal adherence to the official Catholic rites and symbols; rather, it involves an almost mystical attachment to land and community, and a 'soulfulness' that is inherently antagonistic to the Cartesian or scientific account of the world. It is above all a holistic experience, in which the emotions, as much as the intellect, are deeply engaged. The individual is integrated into a vast web of significances that gives meaning to his existence and provides the kind of emotional solace that we associate with 'home' and maternal protection (it is no accident that Mary cults are very important in both countries); thus, separation from the source of this significance is experienced painfully, accompanied by an intense yearning something the Portuguese know as saudade. ${ }^{\text {iv }}$

From this point of view, the scientific revolution, as far as it impinged upon Iberia, did not spell gain but loss - the loss of that intangible moral dimension that the religious know as 'soul', but for which no valid concept exists within the vocabulary of science. Let us listen to the words of the Spanish philosopher, Miguel Unamuno, whose passionate lament for that lost dimension potently illustrates the Catholic perceptions of the hollowness at the core of modernity:

[The nineteenth century saw the growth of a kind of knowledge that was] unphilosophical and technical, dominated by a myopic specialism and by historical materialism /.../ And as it failed to 
satisfy, men continued their quest for happiness, but without finding it, either in wealth, or in knowledge, or in power, or in pleasure, or in resignation, or in a good conscience, or in culture. And the result was pessimism /... / 'Give me my soul again!' - the cry of Faust....

(1922: 298-9)

There were thus powerful emotional motives for resisting the new paradigm that could not be counteracted by a mere appeal to reason. Indeed, reason was an ineffectual weapon in a society where educational levels were extremely low, and whose worldview was organized around a profound sense of the irrational forces at work in the universe (something Unamuno [1912] called 'the tragic sense of life ${ }^{\prime v}$ and which Garcia Lorca later popularized under the notion of duende).

Consequently, the Catholic Church was able to retain its hold for centuries in Spain and Portugal, ensuring that its own theory of knowledge prevailed over the new one that was gaining ground in the countries of northern Europe. That is not to say that modernizing forces did not exist: there were dissenting voices, such as Luíz António Verney, who in 1746 published a tract entitled $O$ Verdadeiro Método de Estudar ('The True Method of Studying'), which vehemently attacked the Jesuit education system and proposed to replace their method of rhetoric and formal discipline with the new scientific approach of Bacon and Galileo; not to mention the intellectuals of the $19^{\text {th }}$ century who struggled against absolutism in the name of liberalism and progress. But these imported ideas found it hard to gain ground. Indeed, in Portugal, there were only two very brief periods before 1974 when Enlightenment views were implemented - the period in office 
of the Marquis of Pombal in the $18^{\text {th }}$ century and the brief Republic of 1910-1926 - and in both cases, the social changes introduced were fleeting and largely reversed afterwards. Aside of these, the country, like its larger neighbour, has been dominated by profoundly Catholic values, first through the Inquisition, which was only finally dismantled in the nineteenth century, and then through the fascist dictatorship that was in power throughout most of the twentieth.

Scholasticism thus remained the dominant method in schools and universities in the Iberian Peninsula for centuries, perpetuating the anthropocentric attitude to knowledge long after it had been abandoned in northern Europe. It gained a new impetus in the $19^{\text {th }}$ century during the backlash against Enlightenment values instigated by Pope Pius IX, which, amongst other measures, formally prescribed Neo-Thomism as the official philosophy for Catholic schools and universities. At the same time, nostalgia was developing in some quarters for the old rhetoric and the values associated with it. As Timmermans (2002:214) points out:

The beginning of the nineteenth century saw a kind of rhetoric that was, on the Old Continent, closely connected to the ideology of the ancien régime and the defence of Christianity. In the face of the Republican 'confusion', but also, little by little, in reaction to the Romantic ideal of the organic 'whole', a number of Catholic rhetors rose up in defence of the virtues of distinction, elegance, nobility and classicism traditionally associated with rhetoric/.../ They sought to restore the authenticity of Christian faith, and also, typically, the 
absolute authority of the Pope and of the monarchs that supported him. At the beginning of the nineteenth century, this was apparently the political and religious ideal pursued by those that were nostalgic for rhetoric. [translated by me from the Portuguese]

Consequently, a mode of discourse began to gain currency in Spain and Portugal that was closely associated to the cause of Catholic reaction. It bore many traits of the old rhetorical tradition (copious eloquence; elaborate sentence structures; abundant use of figures of speech, etc) and was often heavily opaque, since its main purpose was to ‘impress and impose’ (idem: 218).

The fascist regimes that governed Spain and Portugal for most of the $20^{\text {th }}$ century permitted this reactionary current and the rhetoric associated with it to flourish. As Trevor-Roper (1968) points out, this brand of fascism (which he calls 'clerical conservatism' to distinguish it from the 'dynamic fascism' of industrialized countries such as Germany), was the direct heir of the aristocratic conservatism over which the liberal bourgeoisie had triumphed some decades before. Taking root in rural feudal societies where the masses were largely illiterate, and ideologically sanctioned by Catholicism, it represented the values of the ancien régime, standing for an ordered hierarchical undemocratic society in direct opposition to socialism, liberalism, and positivism.

In Portugal, the intellectual elites that made up the ranks of the university had a particularly important role to play in installing and maintaining the dictatorship; indeed, with a government consisting almost exclusively of university professors, Portuguese 
fascism has been called 'fajismo de cátedra' - 'professorial' or 'academic' fascism (Unamuno, 1935). This naturally had consequences upon the attitudes to knowledge and language that prevailed during the period. Unlike the rational, utilitarian and socially empowering knowledge that by this time was dominant in Protestant cultures, learning was not in Portugal something everyone could aspire to. With its almost mystical moral component and authoritarian tinge, it was instead the property of a privileged minority, neither accessible to nor needed by the masses.

Unsurprisingly, much of the discourse used in the academic milieu at this time was designed to 'impress and impose' rather than elucidate. Much of it was dense and impenetrable, and appeared to have an incantatory rather than communicative function (perhaps the verbal equivalent of the elaborate rituals and religious ceremonies that played such an important role in university life). As Pierre Bourdieu pointed out in his famous study of French academic discourse in 1965, this kind of language is radically different from that used by democratic educators:

Speech points to itself, rather than to what it formally signifies. For both orator and auditor, all attention is turned away from the signified. Traditional teaching uses words to seduce. Through a process of osmosis, it promotes the transmission of an already confirmed and legitimate culture, and secures commitment to the values which this contains. Charismatic and traditional teaching stand in marked contrast to the rational use of language, which is suited to democratic education. 
Although Bourdieu did not explore the historical roots of this discourse, his ironic use of religious imagery throughout the essay ${ }^{\mathrm{vi}}$ hints at an ultimately hieratic source. Perry Anderson (2004:6), on the other hand, emphasises the formative role played by rhetoric, as taught at the upper levels of the French educational system. As we have seen, though, there is not necessarily any contradiction here; Catholic discourse all over Continental Europe espoused much of the rhetorical tradition in its attempts to define itself against the upstart invader. Thus, the anthropocentric paradigm never really disappeared from Catholic countries in the way that it did in those more affected by the Reformation, and even today, many Portuguese and Spanish academics of the older generation employ a kind of discourse that has much in common with the 'traditional' style described by Bourdieu.

There is, however, another strand of Portuguese academic discourse that seems to have had a more recent origin, and which I will label 'postmodern' for want of a better term. This seems to have filtered into the country from France during the latter part of the twentieth century, probably via the many Portuguese academics that chose to do their postgraduate degrees there. French culture has traditionally played an important role in forging the tastes of the Portuguese intellectual classes, and as French was also the second language of educated Portuguese until relatively recently, the country was a natural destination for those that wished to study abroad. Hence, there was a ready-made conduit for the various intellectual currents that arose there during the course of the $20^{\text {th }}$ century. 
To a large extent, many of these movements represent a continuation, or reinstatement, of the anthropocentric paradigm in direct opposition to the positivist and empiricist tendencies of the Anglo-Saxon world. In philosophy, phenomenologists like Merleau-Ponty asserted the importance of perception in mediating all knowledge; Saussurean linguistics held language to be a selfcontained system in which meaning was created internally without reference to anything outside; while post-structuralists from Barthes to Foucault emphasized the ways in which discourses construct the very realities they claim to analyse. All of these theories profoundly undermine scientific claims to objectivity and universality, thus disturbing the philosophical foundations upon which the 'authoritative plain style' rests.

Post-modern discourse, then, is anything but plain and transparent. Assuming language to be a creator rather than reflector of realities, these texts revel in ambiguity, with puns, jokes and metaphors forming an intrinsic part of their structure. Indeed, one of the primary characteristics of this kind of discourse is that content is utterly inseparable from the words in which it is formulated; hence, it has more in common with poetic, rather than scientific, language. As Anderson (2004:6) has pointed out, Lacan's Ecrits are ‘closer to Mallarmé than Freud in their syntax', Foucault's oracular gestures 'mingle echoes of Artaud and Bossuet', while 'Lévi-Strauss' Wagnerian constructions, Barthes's eclectic coquetries, belong to the same register'.

Many Portuguese academics working in the humanities today share with the French a blithe disregard of the rigid disciplinary divisions and discursive 
conventions established in Anglo-Saxon culture. Instead, they produce hybrid texts that range unrestrainedly across the human sciences, literature and philosophy, drawing upon the resources of artistic rather than academic forms, and using language in a determinedly non-referential way. These texts present an enormous challenge to the English translator. As Philip Lewis (2000:270) points out with regards to the translation of Derrida, the translator's tendency in expository writing 'to privilege the capture of signifieds, to give primacy to message, content, or concept over language texture' means that s/he may lose sight of 'the order of syntax or metonymy, in which the signifiers of the original are linked to one another and in which that more or less poetic activity that we might term "textual work" is carried on'

In addition to the technical problems of translating discourse that is grounded in an entirely different philosophy of language (a problem common to both the traditional and the postmodern styles of Portuguese academic text, as we have seen), the translator is also faced with an ideological dilemma as regards to the translational strategy to employ. For such texts are almost impossible to publish in the English-speaking world without extensive domestication. Unless the author has the international standing of a Foucault or a Derrida, they will be expected to comply with disciplinary norms as regards content, structure and style, or risk having their text turned down by publishers. This is because, within the scientific paradigm, the construction of knowledge is viewed as a collaborative enterprise, in which the individual investigator has a relatively low profile. ${ }^{\text {vii }}$ In anthropocentric cultures, on the other hand, where professors have an oracular status and where the 
production of texts is perceived in mystical rather than mechanical terms, the whole notion of conforming to norms is anathema. This places the translator in the near impossible situation of having to reconcile two paradigms that are diametrically opposed.

In recent years, however, there seems to have been a shift in the balance of power on the European stage, and the scientific paradigm is now in the ascendancy in Portugal. Consequently, academics today reveal a much greater awareness of English discourse and its norms than they did fifteen years ago, and many of the texts submitted today for translation are couched in a style that is not so different from the English in structure and approach. There are others, though, who, for ideological reasons or sheer force of habit, remain loyal to the anthropocentric world view. This means that there is now a bewildering array of discourses being used in Portugal at present, some of which may enter into conflict within individual texts.

In the following section, I will explore some of the technical and ideological problems raised by some of the texts that have been submitted to me for translation over the years, discussing the options available to the translator in the light of dominant beliefs about what constitutes good writing.

\section{Translating Portuguese Academic Texts}

One of the consequences of the different historical path followed by Portuguese as opposed to English is that the split between 'factual' or objective knowledge, and 'fictional' or subjective representation, that took place after the Enlightenment failed to 
happen. This is reflected in the language on different levels. In Portuguese, like most other Romance languages, the same word (história) is still used for both 'history' and 'story'; ciência (literally 'science') still covers all kinds of knowledge, including that provided by textual analysis, philosophy and even theology; and experiência continues to be used for both 'experience' (subjective, holistic) and 'experiment' (scientific, objective). Similarly, consciência, which split into the moral 'conscience' and the objective 'consciousness' in English, continues to retain both meanings, suggesting an inherent moral underlay to all knowledge.

Furthermore, both Portuguese and Spanish, being closer to Latin, still reveal obvious etymological traces of older meanings that are no longer evident in English. For example, words like 'data' and 'facts', which in English we associate strongly with the scientific paradigm, have cognates in dados/datos and factos/hechos; yet, as these words are derived from the verbs 'to give' and 'to do/make' respectively, they continue stubbornly to suggest 'things given' and 'things done or made' (indeed, in the case of dados and hechos, the nouns are identical with the Past Participle forms of the verb). The very language thereby implies the presence of a giver or a maker.

There are differences on the grammatical level too. The Passive voice, which is so very prevalent in English academic discourse, reflecting the scientific paradigm's emphasis upon the objective world, ${ }^{\text {viii }}$ is used much less in Portuguese. Instead, the Active is much more common, focusing upon human subjectivities and also, interestingly, upon abstractions, which are sometimes made into the agent of an action (see Extract 2 below). Like other Romance languages, Portuguese also has a Reflexive voice that can be used to express the passive idea, thus effectively animating subjects 
which to the English mind would be perceived as inert or abstract and therefore unable to perform the grammatical role of agent (eg. from Extract 1, below: registe-se a já crónica dependência nacional em relação ao trigo de fora, i.e. literally 'let the already chronic national dependence on wheat from abroad register itself').

On the textual level, there are differences not only as regards how the information is organized, but also in the amount of information that is included. One consideration for translators of Portuguese academic texts is how to deal with redundancy, since this is another common feature of this discourse. As we have seen, traditional rhetoric, particularly the grand style of Cicero or the copiousness of Erasmus, both of which clearly influenced Portuguese discourse of the humanities a great deal, valued the mellifluous polysyllabic sentence; this meant that words were often included not for what they added to the meaning, but for their rhythmic pattern or sound, and for the shape they gave to the phrase. Hence, we frequently find duplicated pairs such as teorias correntes $e$ vigentes, uma abordagem coerente e consistente, problemas levantados e suscitados, where the two adjectives qualifying the nouns are essentially synonyms. In English, of course, where meaning rather than aesthetics governs lexical choices, such duplication is considered redundant, and it would be natural to translate such phrases with a single wellchosen adjective (i.e. respectively 'current theories'; 'a coherent approach'; 'problems raised').

The Portuguese propensity for indirectness also causes problems for the English translator. Probably for the stylistic reasons indicated above, there is a tendency on all levels (sentence, paragraph, text) to embed, adorn or defer the main idea to such an extent that a reader untrained in the discourse may not easily perceive the point that is being 
made. Consequently, editors of academic journals may demand that entire chunks of text be completely restructured to bring them in line with target culture expectations. This is what happened as regards the paper from which the following extract (Extract 1) was taken, ${ }^{\text {ix }}$ a history article written in the traditional style, which was submitted to me for translation in 1993 (a literal translation is included between the lines).

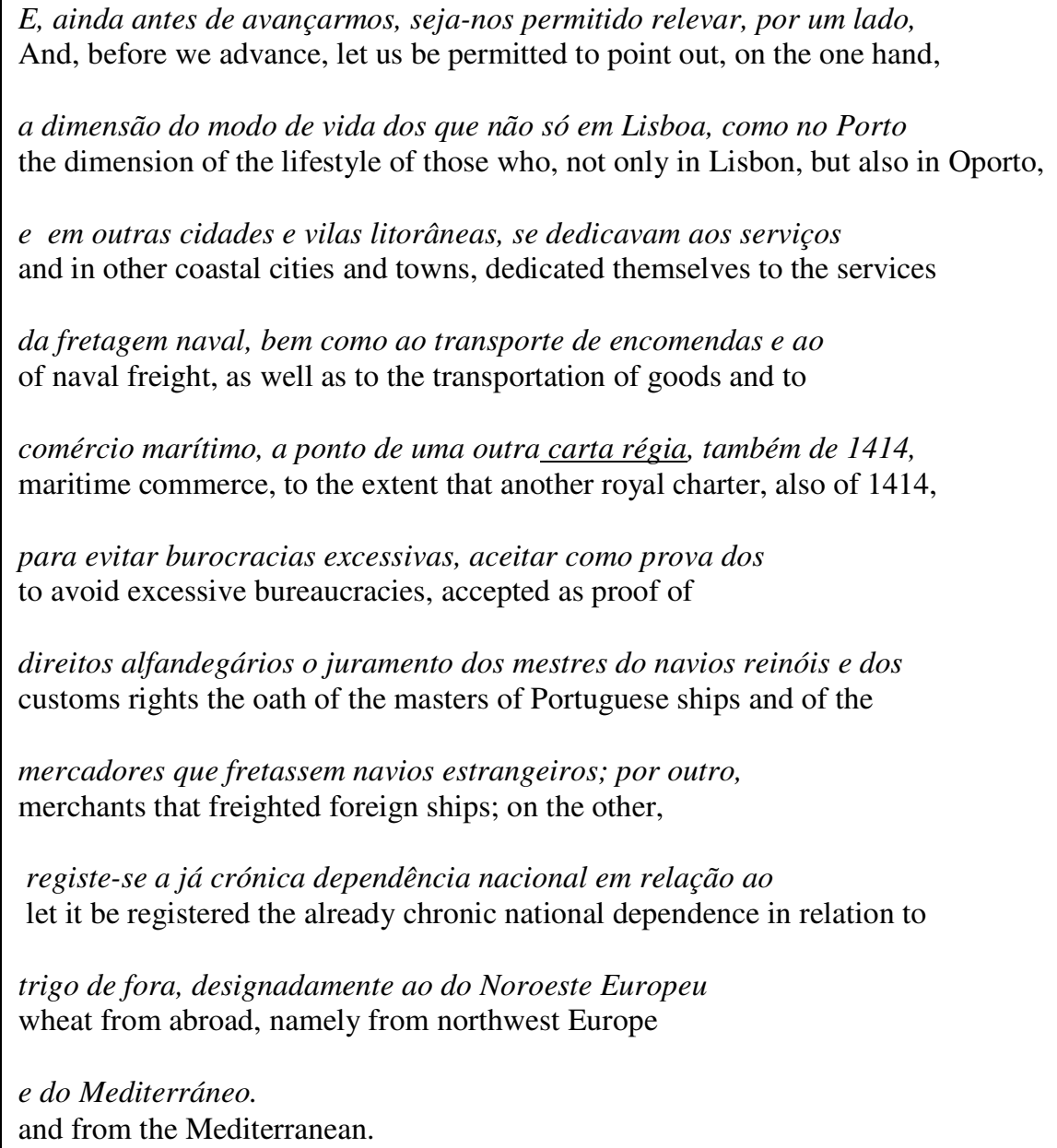

Extract 1. Original text and literal translation.

The complexity of this extract is due largely to the tendency to pack large amounts of information into a single sentence by means of subordination. The 'facts', which in 
English would probably be placed in the main clause, are here presented only indirectly, embedded in a framework that instead highlights the interpersonal dimension of the writer/reader relationship ('And before we go on, allow us to point out...'; 'Let it be registered that...'). Moreover, the precise nature of the connection between the various circumstances described (the royal charter, the lifestyle of the merchants, the dependence on foreign wheat, etc) is not made clear.

The tendency to embed information in indirect structures that focus upon individual or collective subjectivity is very common in Portuguese discourse of the humanities, and claims are often introduced with phrases like Devemos compreender que... 'We should understand that...' Constatamos que.. 'We can see that...'). While it is probably a symptom of the broader tendency in Portuguese to subordinate the referential to the interpersonal, and of course makes a great deal of sense within the anthropocentric paradigm, in English, it is likely to be seen as vague, imprecise and as undermining the truth value of the assertions made (George Orwell famously attacked such structures in his 1941 article, 'Politics and the English Language').

My final translation of the above extract, and the one which was eventually submitted for publication, out of respect for the author's wishes, was in fact a compromise between the author's style and the preferred style in English. It involved splitting the long sentence into several shorter ones, pruning away much of the subordination, and replacing the magisterial 'we' of the first sentence (it is common practice in Portuguese academic discourse for single authors to refer to themselves in the plural) by an impersonal construction. Thus, 'allow us to point out' becomes 'two things 
need to be pointed out', which also functions as a topic sentence, thus imposing English paragraph structure.

Before we proceed, two things need to be pointed out. Firstly, the lifestyle of those involved in the shipping industry, not only in Lisbon, but also in Oporto and other towns and cities along the coast, was so lavish that another royal charter, also issued in 1414 , reduced excessive bureaucracy by allowing the shipmaster's word (in the case of Portuguese ships, and the merchant's in the case of freighted foreign vessels) to be taken as proof of customs rights. Secondly, the country was already registering a chronic dependence on foreign wheat from northwest Europe and the Mediterranean.

Extract 1. Translation A.

A more thorough domestication, however, would require a change in focus. The following version thus removes the interpersonal frame completely, fronts factual information about the royal charter (as a given from which to proceed to the new) and also makes explicit the connections between the various circumstances mentioned.

Another royal charter, also of 1414, reduced bureaucracy by allowing the shipmaster's word (in the case of Portuguese ships, the merchant's in the case of freighted foreign vessels) to be taken as proof of customs rights. This illustrated the immense power wielded by those involved in the shipping industry in Lisbon, Oporto and other coastal cities and towns, and also reflected the chronic national dependence on foreign wheat from northwest Europe and the Mediterranean.

Extract 1. Translation B.

As we can see from these three English versions of the same Portuguese sentence, the process of adapting this text for foreign consumption involves far more than merely replacing one chain of signifiers with another. The very organization of the discourse the information that is focused upon or omitted, the length of clauses, degree of explicitness etc - reflects a whole different attitude to language and to knowledge. Yet this is not usually recognized by the editors of academic journals. Given the current 
balance of power between the two paradigms on the world stage, such texts are generally rejected out of hand as being badly written, unfocused or inappropriate.

Another characteristic of Portuguese discourse that may cause problems for the translator is the habit of deferring the main information instead of presenting it in first place, as might be expected in English. This may operate on the level of the paragraph, with the 'topic sentence' (if one exists) coming at the end; it also functions on the level of the sentence, with a penchant for cataphora. The two sentences that make up the following paragraph (Extract 2) are both organized in this way . ${ }^{\mathrm{x}}$

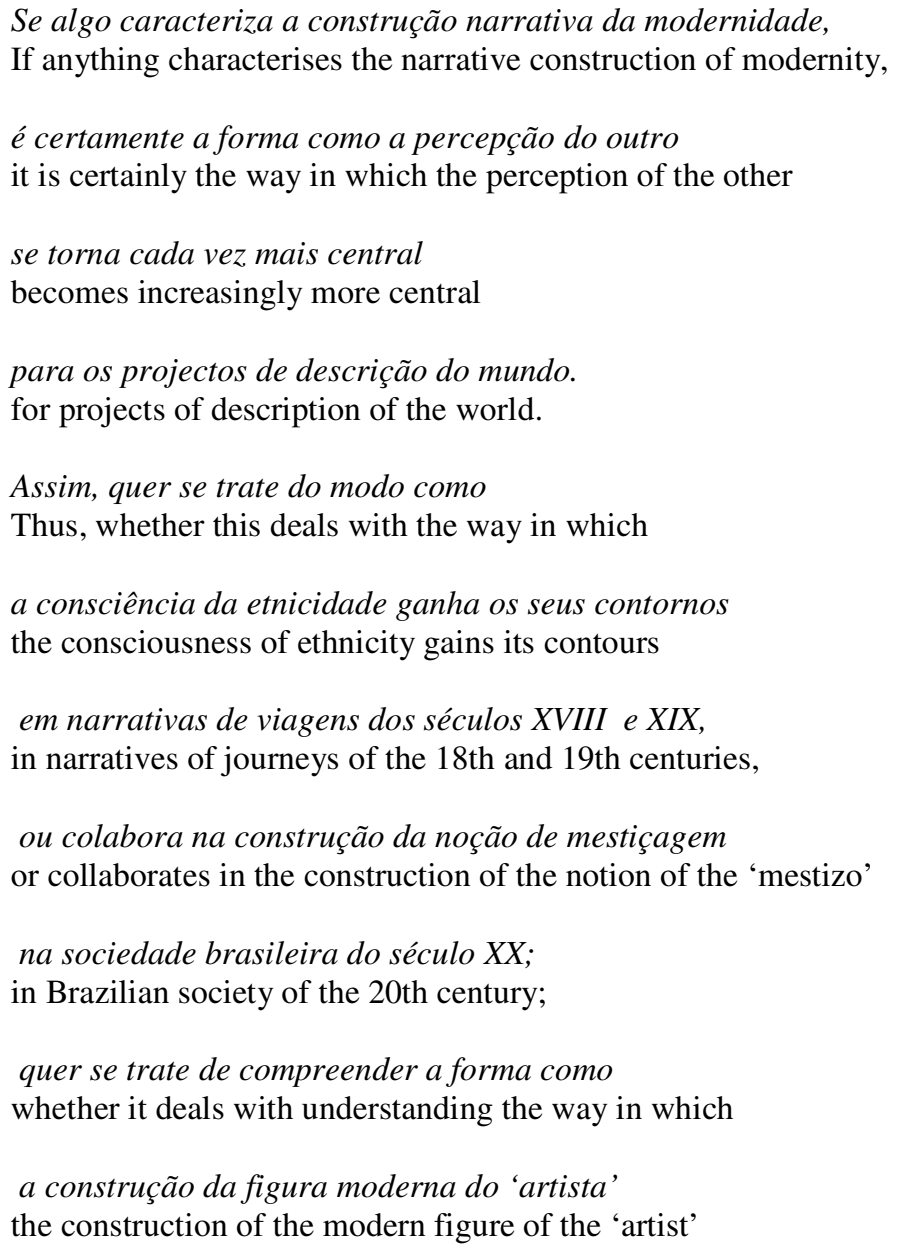




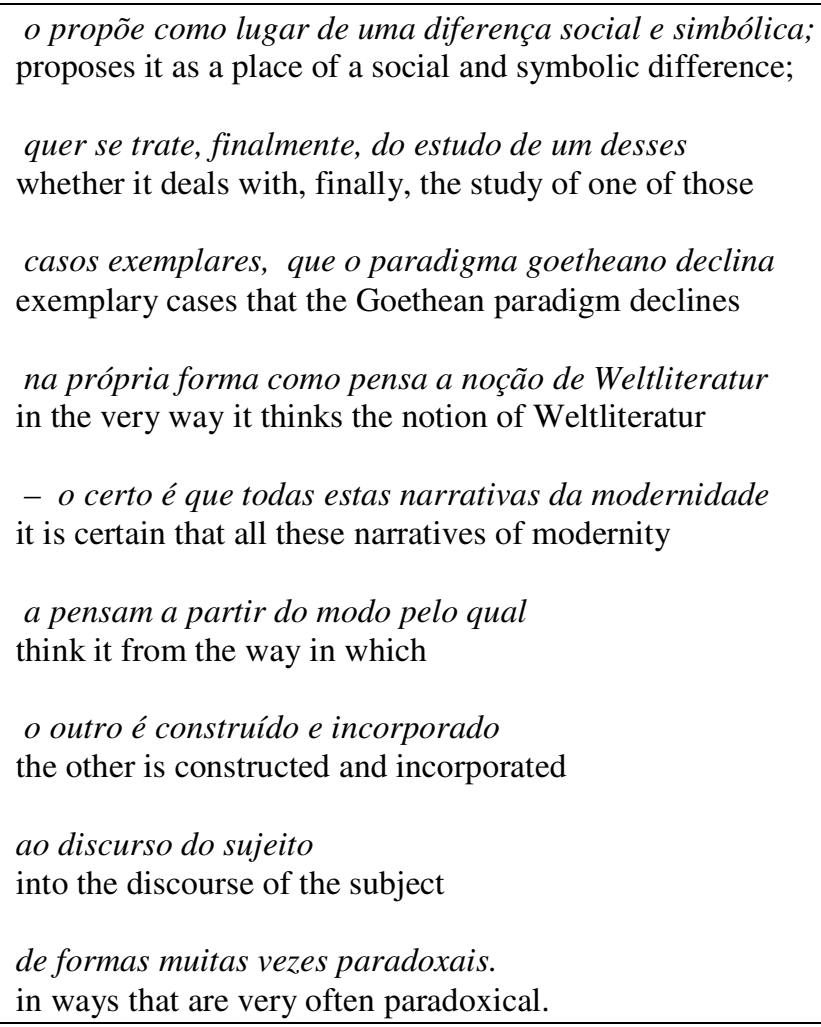

Extract 2. Original text and literal translation.

Although with some manipulation, English does permit a similar word order to the original (as in my final version, below), a more complete domestication would probably require an inversion of the long sentence so that the main clause is presented in first position. ${ }^{\mathrm{xi}}$ What is completely alien to English, however, is persistent use of an abstract subject with a material or verbal process in the Active voice (i.e. 'the consciousness of ethnicity collaborates..'; 'the Göethean paradigm declines'; 'the construction of the figure of the artist proposes...' etc), a form which seems to suggest that the abstract fruits of human thought have a kind of autonomy and are able to produce effects in the world independent of the individuals that call them into being. ${ }^{\text {xii }}$ In translation, these have to be reformulated into passives or nominalised, thus effectively obliterating the underlying philosophical difference. 
If the narrative construction of modernity can be characterised by anything at all, it is by the increasingly central position occupied by perceptions of the Other in descriptions of the world. Whether concerned with the development of ethnic awareness in travel literature of the $18^{\text {th }}$ and $19^{\text {th }}$ centuries, and its part in the construction of the notion of the mestizo in Brazilian society in the $20^{\text {th }}$ century; the construction of the modern figure of the 'artist' as a locus of social and symbolic difference; or the study of any of these examples, epitomised by the Goethean paradigm in the notion of Weltliteratur, all these narratives of modernity are organised around the construction of the Other and the often paradoxical ways in which this construction is incorporated into the discourse of the subject.

\section{Extract 2. Translation.}

This extract of course draws to some extent upon postmodern discourses in both content and form, and as such is representative of much of what is being produced in humanities departments in Portugal and elsewhere. Extract 3, ${ }^{\text {xii }}$ however, is more contentious, being in the area of psychology, a field more obviously perceived as 'scientific' in Anglo-Saxon culture. Assuming from the outset a phenomenological stance in the tradition of Husserl, Sartre and Merleau-Ponty, the author rejects the impersonality of the scientific paradigm and instead embraces a passionate poetic style that, in English, would be more appropriate in a literary genre. The text is divided into 26 short numbered paragraphs, some no more than a sentence long, each of which presents the voice of a different subjectivity, and is illustrated in places with excerpts of poetry by famous writers from the Portuguese canon.

\section{6}

Pelo amor me ofereço em holocausto pela vida do outro. Devoto-me, não já ao seu corpo, mas ao seu desejo, à sua subjectividade, ao seu espírito.

17

(Citação de Camões)

Já não vejo, e sobretudo não me vejo, pelos meus olhos, mas pelos olhos do outro. E à sua visão me moldo como objecto. Se o outro me 
quer alegre, eu rio, mas choro se ele me quiser triste. Sou activo ou passivo, inteligente ou embotado, consoante os seus desejos.

Se o outro me quer sem corpo, o meu corpo deixa de existir para mim. Deixo os prazeres e a comida, e ele vai desaparecendo. Mas sempre sobra corpo, e por isso me acho gordo. Podia bem ser esse o desejo do escrupuloso pai amado pela filha anoréctica.

Extract 3. Original text.

16.

In love, I offer myself to be burnt up by the life of the other. I devote myself, no longer to her body, but to her desire, her subjectivity, her spirit.

(lines of poetry by Camões)

17.

I no longer see. In particular, I no longer see myself through my own eyes, but through the eyes of the other. If the other wants me happy, I laugh, but I cry if he wants me sad. I am active or passive, intelligent or feeble, in accordance with his wishes.

If the other wants me to be incorporeal, my body stops existing for me. I give up pleasures and food, and my body withdraws. But there is still too much body, and so, I think I am fat. This could well be the desire of the anorectic daughter towards her beloved but scrupulous father.

Extract 3. Translation.

The language in this text is relatively simple and so can be translated fairly literally. However, it is utterly alien to target culture expectations, and as such, is not publishable in English as scientific discourse. As this author has discovered with other works he has written, unconventional or uncategorisable texts will only ever be considered by English publishers when there is incontrovertible evidence of their commercial and academic success in a number of other countries. Otherwise, they are rejected out of hand.

My final example (Extract 4) ${ }^{\text {xiv }}$, from a text that I was asked to translate in 2001, is particularly interesting since, in content and approach, it straddles the two paradigms. The subject is Fatima, the religious shrine where visions of the Virgin Mary were reportedly seen in 1917 and which has since become a major pilgrimage site. It is a highly-charged symbol within Portuguese culture, which few are able to discuss in 
objective terms. However, the author's approach to her topic is scientific in all respects: the aims of the study are presented in the technical terminology of Human Geography (indeed the research was carried out under the auspices of a Geography Research Unit); the methods are empirical (extensive surveys of pilgrims at the site); and the results are presented statistically, accompanied by graphs, tables and diagrams. The discourse too is remarkably objective. In relating the legend of the visions, the author distances herself from the claims by the use of reported speech (something which noticeably fails to occur in most press coverage of Fatima-related events):

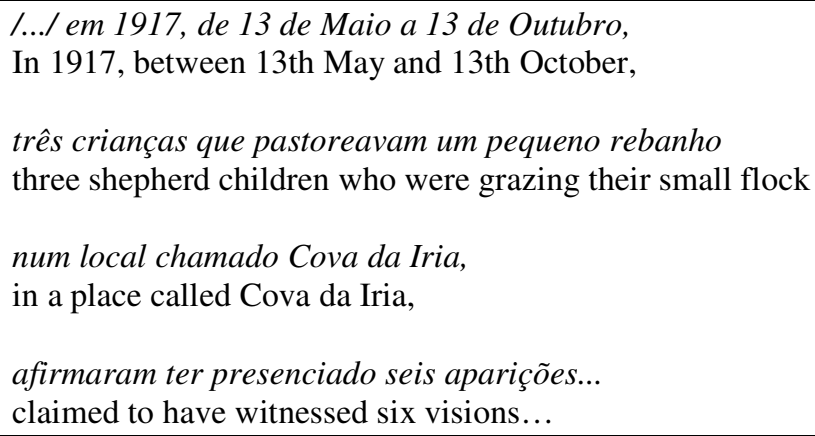

The notion of the 'sacred' is also treated not with the charged language of the believer, but with the detachment of the anthropologist:

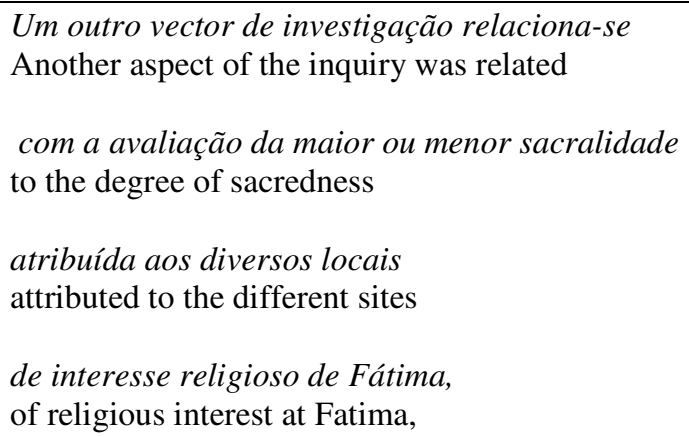




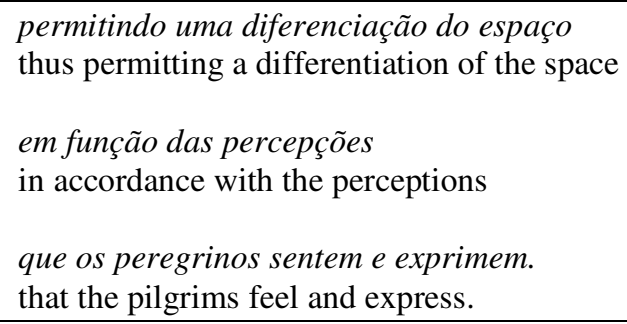

Extract 4b. Original text and literal translation.

This distance is maintained in the mobilization of terms from the discourse of consumerism and advertising:

Neste sentido, bem se poderá afirmar que
Thus, it could well be claimed that
o peregrino a pé faz parte,
foot pilgrims have a part
no fenómeno social que Fátima também é,
in the social phenomenon that Fatima also is
da sua imagem de marca
in its brand image.

\section{Extract 4c. Original text and literal translation.}

[i.e. 'Thus, foot pilgrims appear to have a part to play in the construction of the brand image of Fatima as a social phenomenon'.]

Within such a consistently objective approach to the topic, it therefore comes as a shock to encounter the term Nossa Senhora ('Our Lady'), used each time the author makes reference to the Virgin Mary. For this is a term from the religious paradigm, implying identification with the Catholic community and belief in the verity of the supernatural phenomena at the heart of the cult. As such it represents a clash of discourses, something that might perhaps not be noticed by the Portuguese reader, but which is startling in 
English. The translator's dilemma here is whether or not to neutralize this term, for not only is it stylistically inappropriate in a geography article, it also effectively undermines the scientific stance and objectivity of the article as a whole. By collapsing the distance between the researcher and the object of study so carefully set up elsewhere, it infringes one of the most important institutional imperatives of science, namely the norm of disinterestedness (cf. Merton, 1973: 275-277).

Ultimately, however, the problem was diminished by the fact that the article was eventually published in a highly specialized journal dealing exclusively with the phenomena of pilgrimages and religious tourism, in which context such hybrid discourse may not be out of place. This suggests a certain blurring of the boundaries between the two paradigms in some circles; or that the anthropocentric paradigm today is more receptive to the aims and methods of science than it was in Galileo's day. Certainly, as my other examples have shown, it is much more receptive to science than the scientific paradigm is to non-science, which illustrates better than anything the shift in the balance of power that has taken place over the last 500 years. Bolstered by capitalism and technology, the scientific worldview at present determines what may legitimately be considered as knowledge, and its gatekeepers, in the form of scientific journals, conference organizers and (dare we say it!) translators, ensure that aliens are either domesticated or kept out.

However, what becomes clear in the endless dance of ideologies and worldviews that the historical study of translation reveals is that no one is ever definitively proved right. Theories come and theories go, and the one that holds sway at any given moment depends upon the culture that happens to be at the centre of the polysystem and the power 
structures that support it. Even when the hegemony appears to have an almost global reach, the dissenting voices are never silenced completely. Instead they mobilize around the periphery of the system, infiltrating where they can and awaiting their chance. For, as Kress so eloquently points out (1998:7), their aim is imperialistic; it is nothing less than to colonise the social world.

If we look carefully at the system in which we presently live, we can see signs of weakening in the dominant paradigm. As this study suggests, the anthropocentric worldview was never totally extinguished by the scientific revolution, but instead smouldered on away from the epicentre of power, setting up alternative centres around the edges where its discourses could flourish. In recent years, some of these have begun to offer serious challenges to the hegemonic ideology. Whether taking the form of poststructuralist theory, neo-Thomism or Islamic fundamentalism, there are a number of alternatives to the scientific paradigm that are gaining support on the wider stage.

In the meantime, there have also been manifestations of discontent at the centre of the system. New academic disciplines and approaches such as the sociology of knowledge, discourse analysis and ethnomethodology, all of which developed out of the scientific paradigm, now threaten to undermine it from within ${ }^{\mathrm{xv}}$ while the dramatic growth of New Age religions, Creationism and different forms of mysticism in society at large suggests that anthropocentrism is flourishing in a series of different guises.

So while the scientific paradigm is still clearly dominant in western academia, suppressing or domesticating alternative forms of knowledge and the discourses that encode them, there is reason to believe that this situation will not remain for long. We 
appear to be on the brink of a new paradigm shift in which anthropocentrism, in one shape or another, may once again take centre stage.

Galileo, if he knew, would be turning in his grave.

\section{REFERENCES}

Anderson, Perry. 2004. 'Dégringolade' in London Review of Books, Vol. 26, No. 17.

Bercovitch, Sacvan. 1975. The Puritan Origins of the American Self, New Haven \& London: Yale University Press.

Bourdieu, Pierre et al. 1994 [1965]. Academic Discourse, California: Stanford University Press.

Cheke, Marcus. 1953. 'The Portuguese Character' in Portugal and Brazil, H. Livermore (Ed.), Oxford: Oxford University Press.

Croll, Morris, W. 1969 [1966] "Attic Prose: Lipsius, Montaigne, Bacon" in Attic and Baroque Prose Style (Ed. Max Patrick and Robert Evans with John Wallace), New Jersey: Princeton University Press.

Ding, Dan. 1998. 'Rationality Reborn: Historical Roots of the Passive Voice in Scientific Discourse' in Essays in the Study of Scientific Discourse: Methods, Practices and Pedagogy, J. Battalio (Ed), Stamford \& London: Ablex.

Even-Zohar, Itamar. 1990. 'Polysystem Theory' in Poetics Today, Vol. 11. No. 1, pp 851.

Fairclough, Norman. 1992. Discourse and Social Change, Cambridge: Polity Press. 
Halliday, Michael. 1993. 'On the Language of Physical Science' in Writing Science: Literacy and Discursive Power, M.A.K. Halliday \& J.R. Martin (Eds), Pittsburgh: University of Pittsburgh Press.

Hill, Christopher. 1997 [1965]. Intellectual Origins of the English Revolution Revisited, Oxford: Oxford University Press.

Kress, Günther. 1998. Linguistic Processes in Sociocultural Practice, Oxford: Oxford University Press.

Lakoff, George \& Johnson, Mark. 1980. Metaphors We Live By, Chicago: University of Chicago Press.

Lewis, Philip, 2000. 'The Measure of Translation Effects' in The Translation Studies Reader, Lawrence Venuti (Ed.), London \& New York: Routledge.

Lourenço, Eduardo. 1988. O Labirinto da Saudade, Lisbon: Don Quixote.

Merton, Robert K. 1973. 'The Normative Structure of Science' [1942] in The Sociology of Science: Theoretical and Empirical Investigations, Chicago and London: University of Chicago Press, pp.267-278.

Merton, Robert K. 2001 [1970]. Science, Technology and Society in Seventeenth-Century England, New York: Howard Fertig.

Partridge, A.C. 1969. Tudor to Augustan English: a Study in Syntax and Style from Caxton to Johnson, London: André Deutsch.

Potter, Jonathan. 1996. Representing Reality: Discourse, Rhetoric and Social Construction, London, Thousand Oaks \& New Delhi: Sage Publications. Serrão, Joel. 1960. Temas de Cultura Portuguesa, Lisbon: Atica. Snow, C.P. 1998 [1959] The Two Cultures, Cambridge: Cambridge University Press. 
Tawney, R.H. 1938 [1922]. Religion and the Rise of Capitalism, Middlesex: Penguin.

Timmermans, Benoît. 1999 'Renascimento e Modernidade da Retórica' in Michel

Meyer, Manuel Maria Carrilho \& Benoît Timmermans, História da Retórica,

Lisbon: Temas e Debates, (translated from French by Maria Manuel Berjano).

Trevor-Roper, Hugh. 1968. 'The Phenomenon of Fascism' in European Fascism, S.

Woolf (Ed.), London: Weidenfeld \& Nicholson.

Unamuno, Miguel. 1921. The Tragic Sense of Life, transl. J.E.Crawford Flitch, London:

Macmillan \& Co.

Unamuno, Miguel. 1935. 'Comentário: Nueva Vuelta a Portugal' in Ahora, 3.7.

Venuti, Lawrence. 1995. The Translator's Invisibility: a History of Translation, London \& New York: Routledge.

Vickers, Brian. 1993. 'The Recovery of Rhetoric: Petrarch, Erasmus, Perelman’ in The Recovery of Rhetoric: Persuasive Discourse and Disciplinarity in the Human Sciences, R.H.Roberts \& J.M.M. Good (Eds), Charlottesville: University Press of Virginia.

Weber, Max. 1992 [1930] The Protestant Ethic and the Spirit of Capitalism, trans.

Parsons, T. New York and London: Routledge.

White, Hayden. 1997. 'The Suppression of Rhetoric in the Nineteenth Century' in The Rhetoric Canon, Schilgen (Ed.), Detroit: Wayne State University.

\footnotetext{
i I am not using 'anthropocentrism' here in its traditional binary relationship with 'theocentrism', but rather setting up a new opposition between a language-oriented classically- and Christian-derived humanism, on the one hand, and the worldview of academic science on the other.

${ }^{\text {ii }}$ For an overview of Polysystems Theory, see Evan-Zohar, 1990.

iii Of course it is not easy to say which came first, social or ideological change. The value system that had sustained the old feudal structure could no longer respond to the needs of a new social class that was getting rich on trade and was eager for knowledge and social advancement; consequently, there were
} 
important shifts in attitude to questions such as the legitimacy of money making and the search for knowledge. See Robert Merton (2001[1970] and Christopher Hill (1997 [1965]) on the connections between Protestantism and science; Max Weber (1992 [1930]) and R.H.Tawney (1938 [1922] ) on the relationship between Protestantism and capitalism, the development of the work ethic and the rise of the bourgeoisie.

iv These notions have long been commonplaces in analyses of Iberian culture. See for example Serrão, (1960); Cheke (1953), and more recently, Lourenço (1988).

${ }^{v}$ Original title, Del Sentimiento Trágico de la Vida, Madrid, Barcelona \& Buenos Aires: Renacimiento, 1912.

${ }^{\mathrm{vi}} \mathrm{Eg}$. 'language is first and foremost a marvellous incantation whose whole justification lies in placing the disciple in a fit state to receive grace' (p.19); 'the propitiatory ritual of erudite citation pays homage to celebrated masters or to culture...' (p.20); 'destined above all to play the part of the faithful at a church service, students must answer with ritual responses' (p.11); 'through a kind of incantatory or sacrificial rite, [students] try to call up and reinstate tropes, schemas or words which to them distinguish professorial language' (p.4). The italics are mine.

vii See Merton (1973:267-278) on the ethos of modern science.

viii See Ding (1998) for a study of the development of the Passive Voice in scientific discourse.

ix João Marinho dos Santos (1993). The article remained unpublished in English after rejection by a publisher on the grounds that the style used was too remote from the house style of the journal. This extract is reproduced with the kind permission of the author.

${ }^{\mathrm{x}}$ From the blurb on the back cover of conference proceedings, ACT3: Narratives of Modernity: the Construction of the Other, Colibri/CEC, Lisbon 2001.

${ }^{\mathrm{xi}}$ In practice it was not necessary to domesticate further, since the translation was commissioned by the research unit that published the conference proceedings from which this extract came.

xii This notion may not be too far away from the 'tragic view of life' of Unamuno, Lorca and of course the Ancient Greeks, according to which human action is inherently alienable, subject to influence by the irrational forces at work in the universe.

xiii J. L. Pio Abreu. 'A Fenomenologia de Sexualidade: do Desejo ao Amor' ('The Phenomenology of Sexuality: from Lust to Love'), Chapter 7 of $O$ Tempo Aprisionado: Ensaios não-Espiritualistas sobre o Espírito Humano. Coimbra (Portugal): Quarteto Editora: 2000:139-149. Extract reproduced with the kind permission of the author.

${ }^{x i v}$ Maria da Graça Poças Santos (2001). 'The Sacred Space of Fatima as Perceived and Experienced by Foot Pilgrims', Peregrinus Cracoviensis, Krakow: Institute of Geography and Spatial Management, Jagiellonian University. No.12:11-28.

${ }^{\mathrm{xv}}$ See Potter (1996) for a detailed account of these challenges to the dominant view of reality. 